\title{
Webinar Sebagai Metode Pengumpulan Data diEra Pandemi Bagi Para Peternak Indonesia
}

\author{
Ariesya Aprillia ${ }^{1}$, Agus Aribowo ${ }^{2}$, Allen Kristiawan ${ }^{3}$, Amelina Apricia Sjam ${ }^{4}$, Anny Nurbasari ${ }^{5}$, Cen \\ $\mathrm{Lu}^{6}$, Chandra Kuswoyo ${ }^{7}$, Felicia Abednego ${ }^{8}, \mathrm{Ida}^{9}$, Ika Gunawan ${ }^{10}$, Kartika Imasari Tjiptodjojo ${ }^{11}$, \\ Kezia Kurniawati Nursalin ${ }^{12}$, Nonie Magdalena ${ }^{13}$, Rony Setiawan ${ }^{14}$, Rully Arlan Tjahyadi ${ }^{15}$, Rusli \\ Ginting Munthe ${ }^{16}$,Audrey Gabrielle ${ }^{17}$, Casuarina Putri Benedicta Sihombing ${ }^{18}$, Christine Aliwinoto ${ }^{19}$, \\ Eric Spiro Lee ${ }^{20}$, Festi Remisia Daeli ${ }^{21}$ \\ Program Studi S-1 Manajemen Fakultas Bisnis Universitas Kristen Maranatha \\ Email:ariesya.aprillia@eco.maranatha.edu
}

\begin{abstract}
Abstrak - Perguruan Tinggi merupakan salah satu lembaga yang berkontribusi pada pembangunan SDM Unggul Indonesia. Internalisasi nilai kearifan lokal pada civitas akademika Perguruan Tinggi di Indonesia melalui kebijakan Tri Dharma Perguruan Tinggi dan Merdeka Belajar Kampus Merdeka (MBKM). Salah satu implementasi kebijakan melalui kegiatan Pengabdian kepada Masyarakat (PkM). Kegiatan PkM ini bertujuan membantu salah satu perusahaan yang memproduksi Farmasi peternakan di Indonesia untuk melakukan survei kepuasan pelanggan. Metode pelaksanaan menggunakan metode konsultasi yang hasilnya menjadi pembelajaran bagi tim pengabdi dan pelaku usaha untuk memecahkan masalah mengenai kepuasan pelanggan dan penggunaan metode penelitian. Tahapan diawali: pertama, pemberian knowledge kepada mahasiswa riset pasar dalam bentuk kuliah tamu; kedua, mengadakan webinar online sebagai media pengumpulan data survei; dan tahap akhir, melakukan Focus Group Discussion (FGD) dengan perusahaan farmasi perternakan sebagai mitra kerjasama. Dengan semangat nilai kreativitas dan kemampuan beradaptasi maka tim pengabdi dapat melaksanaan kegiatan PkM ini dalam kondisi pandemi. Peserta kegiatan ini adalah peternak di Indonesia yang merupakan pelanggan dari perusahaan farmasi perternakan. Metode pengumpulan data PkM ini menggunakan webinar online. PkM ini juga menggunakan surveyor mahasiswa sebagai moderator dalam pengisian kuesioner kepuasan secara kualitatif dan kuantitatif. PkM ini menggunakan metode analisis data statistik deskriptif dan metode analisis ilustratif. Hasil adalah media webinar online sebagai metode pengumpulan data untuk para peternak masih belum optimal dan perlu perancangan kembali dengan memperbaiki beberapa hambatan pelaksanaan yaitu: pengetahuan, keinginan, dan karakteristik responden, serta karakteristik panitia pelaksana sehingga terjadi penyesuaian dengan media yang
\end{abstract}

digunakan. Luaran PkM ini adalah modul pembelajaran yang berhubungan dengan riset pasar dan metode penelitian.

Kata kunci-PkM, Metode Konsultasi, Webinar Online.

Abstract-Higher Education is one of the institutions that contribute to the development of Indonesia's Superior Human Resources. Internalization of the value of local wisdom in the academic community of higher education institutions in Indonesia through Tri Dharma Perguruan Tinggi policy and Merdeka Belajar Kampus Merdeka. One of the policy implementations is through Community Service (PkM) activities. This PkM activity aims to help a company that produces livestock drugs and vaccines in Indonesia to conduct a customer satisfaction survey. This implementation method uses the consultation method, the results of which are lessons for the service team and business actors to solve problems regarding customer satisfaction and the use of research methods. The stage begins: first, sharing knowledge to market research students in the form of guest lectures; second, carry out online webinars as a medium for collecting survey data; and the final stage, conducting a Focus Group Discussion (FGD) with livestock pharmaceutical company as a cooperation partner. With the spirit of the value of creativity and adaptability, the service team can carry out this PkM activity in a pandemic condition. The participants of this activity are farmers in Indonesia who are customers of livestock pharmaceutical company. This PkM data collection method uses online webinars. This PkM also uses student surveyors as moderators in filling out satisfaction questionnaires qualitatively and quantitatively. This PkM uses descriptive statistical data analysis methods and illustrative analysis methods. The result is that the online webinar media as a data collection method for farmers is still not optimal and needs to be redesigned by fixing several implementation barriers, namely: knowledge, desires, and characteristics of respondents, as well as the characteristics 
of the implementing committee so that adjustments occur with the media used. The output of this PkM is a learning module related to market research and research methods.

Keywords-PkM, Consultation Methode, Online Webinar.

\section{Pendahuluan}

Budaya merupakan elemen dasar yang membentuk kelompok untuk bertumbuh dan berkembang. Dengan membangun budaya kelompok yang sama maka kelompok akan memiliki cara kerja yang sama untuk mencapai visi dan misi. Budaya mengandung nilai-nilai yang perlu dibagikan, dipersepsikan, dan diimplementasikan oleh seluruh anggota kelompok. Nilainilai menjadi penting bagi pembentukan budaya kelompok. Seperti yang dijelaskan oleh Triguno (1995), budaya merupakan pandangan hidup yang mengandung nilai-nilai sebagai pendorong untuk melakukan pekerjaan [1].

Tulisan ini lebih menekankan pada bagaimana negara akan menjadi negara yang bertumbuh dan berkembang jika seluruh warga memiliki karakter nilai yang sesuai dengan budaya negara tersebut. Pemerintah perlu melakukan internalisasi kepada warga negara untuk dapat memahami, menghayati, dan menguasai budaya negara tersebut sehingga setiap warga negara dapat menerapkan budaya negara dalam peran dan statusnya di masyarakat.

Salah satu subjek yang diangkat dalam tulisan ini adalah peran para pendidik sebagai masyarakat Indonesia. Pemerintahan Indonesia periode 2019-2024 memiliki visi membangun Sumber Daya Manusia (SDM) Unggul. Sumber daya manusia di era revolusi industri 4.0 perlu memiliki kualitas yang mumpuni, bisa melakukan penyesuaian yang cepat dan fleksibel, serta mampu menanggapi setiap perubahan yang terjadi dari lingkungan makro dan mikro [2]. Kemampuan menerima dan beradaptasi perlu menjadi literasi budaya bagi dunia pendidikan di Indonesia [3].

Kebijakan Pemerintah Indonesia untuk menghasilkan SDM Unggul yaitu Tri Dharma Perguruan Tinggi dan Merdeka Belajar Kampus Merdeka (MBKM). Humas Dirjen Dikti Kementrian Pendidikan dan Kebudayaan mengungkapkan bahwa seluruh civitas Perguruan Tinggi perlu melakukan Tri Dharma Perguruan Tinggi yang bertujuan untuk menghasilkan centre of excellence dari pendidikan yang berkolaborasi dengan penelitian menuju pada pengabdian kepada masyarakat sehingga tercapai kesejahteraan masyarakat [4]. Selain itu, kebijakan lain yang baru diluncurkan adalah Merdeka Belajar Kampus Merdeka (MBKM). Kebijakan MBKM bertujuan untuk menghasilkan lulusan yang menguasai berbagai keilmuan yang siap kerja dan cepat tanggap terhadap perubahaan [5].
Kebijakan Tri Dharma Perguruan Tinggi dan MBKM ini merupakan salah satu wujud internalisasi nilai kearifan lokal yang dimiliki oleh bangsa Indonesia di dunia pendidikan. Nilai kearifan lokal yang kreatif menghasilkan ide dan mampu berdaptasi serta cepat tanggap terhadap perubahan lingkungan perlu dimiliki oleh SDM Perguruan Tinggi sehingga dapat menghasilkan SDM Indonesia yang unggul dan mampu bersaing di dunia.

SDM Indonesia yang unggul perlu menjadi teladan bagi dunia dengan menghasilkan karya yang inovatif kreatif dan mendorong orang lain untuk berkarya sehingga dapat berkontribusi bagi kesejahteraan masyarakat. Hal ini sesuai dengan nilai kearifan lokal yang dipelopori oleh seorang pelopor sistem pendidikan di Indonesia yaitu Ki Hajar Dewantara [6]. Sistem Pendidikan Nasional Indonesia merupakan sistem mencerdaskan bangsa Indonesia didasari dari budaya yang diakui oleh bangsanya sendiri. Seperti yang ditulis oleh Nata (2015), semboyan Ki Hajar Dewantara "ing ngarso sung tulodo, ing madya mangun karso, tut wuri handayani", artinya ketika pendidik berada di depan, pendidik harus menciptakan, harus mengeluarkan gagasan atau ide-ide yang dimilikinya, serta memberikan arahan dan dorongan kepada peserta didik [6].

Berdasarkan kebijakan pemerintah Indonesia yaitu Tri Dharma Perguruan Tinggi dan MBKM, maka Perguruan Tinggi di Indonesia sebagai salah satu lembaga pendidikan perlu mendukung keberhasilan kedua kebijakan tersebut untuk menghasilkan SDM Unggul. Perguruan Tinggi di Indonesia perlu menyusun program pendidikan yang mendukung kebijakan Tri Dharma Perguruan Tinggi dan MBKM. Salah satu rencana strategis yang perlu dikembangkan adalah adanya kerjasama dengan industri untuk dapat menyelaraskan antara teori dan praktik sehingga diharapkan dosen dan mahasiswa dapat memberikan karya yang bermanfaat bagi kesejahteraan masyarakat.

Program Studi Sarjana Manajemen dan Program Magister Manajemen Fakultas Bisnis Universitas Kristen Maranatha memiliki rencana strategis yang mendukung kebijkan Tri Dharma Perguruan Tinggi dan MBKM serta Rencana Strategis Universitas Kristen Maranatha yaitu melakukan kolaborasi di bidang Tri Dharma Perguruan Tinggi (Pendidikan, Penelitian, dan Pengabdian kepada Masyarakat). Dalam mewujudkan rencana strategis tersebut, Program Studi Sarjana Manajemen dan Program Magister Manajemen Fakultas Bisnis Universitas Kristen Maranatha melakukan kerja sama dengan salah satu perusahaan farmasi perternakan di Indonesia. Kerja sama ini bertujuan untuk membantu perusahaan melakukan survei kepuasan pelanggan farmasi peternakan.

Dalam menunjang kegiatan ini maka dosen dan mahasiswa perlu melakukan kegiatan PkM. Salah satu 
bentuk kegiatan PkM di Universitas Kristen Maranatha adalah mengimplementasikan kepakaran dosen. Salah satu bentuk implementasi kepakaran dosen adalah memberikan solusi kepada perusahaan sehingga dapat memberikan keuntungan bagi perusahaan dan pengalaman praktis bagi dosen dan mahasiswa yang akhirnya menjadi jembatan atau wadah untuk mensinkronisasikan antara teori dan praktik.

Berdasarkan penjelaskan tersebut, dosen dan mahasiswa di Program Studi Sarjana Manajemen dan Program Magister Manajemen Fakultas Bisnis Universitas Kristen Maranatha mengadakan kegiatan PkM untuk membantu salah satu perusahaan farmasi perternakan di Indonesia dalam bentuk survei kepuasan pelanggan farmasi perternakan di 9 (Sembilan) wilayah Indonesia yaitu: Bali dan Sekitarnya, Jakarta dan Sekitarnya, Jawa Barat, Jawa Tengah, Jawa Timur, Kalimantan, Sulawesi, serta Sumatra.

Saat ini kondisi Pandemi Covid-19 sedang melanda seluruh negara di dunia termasuk Indonesia. Pandemi Covid-19 merupakan wabah yang menurunkan kesejahteraan masyarakat seluruh dunia. Pemerintah menetapkan kebijakan Pembatasan Sosial Berskala Besar (PSBB) untuk seluruh daerah di Indonesia sehingga setiap warganya wajib melakukan $5 \mathrm{M}$ yaitu: mencuci tangan, menjaga jarak, menjauhi kerumunan, menggunakan masker, mengurangi mobilitas [7].

Kebijakan PSBB mengakibatkan tim pengabdi dan perusahaan perlu memikirkan ulang media yang digunakan untuk melakukan survei kepuasan. Tim pengabdi dan perusahaan perlu merancang secara kreatif dan adaptasi bagaimana sebaiknya proses survei dapat dilakukan tanpa bertentangan dengan kebijakan 5M. Kondisi ini meningkatkan kreatifitas seluruh pihak yang terlibat dalam kegiatan pengabdian masyarakat ini untuk menemukan solusi dari setiap permasalahan yang terjadi akibat pandemi.

Kegiatan PkM ini bertujuan membantu salah satu perusahaan yang bergerak di bidang farmasi peternakan untuk melakukan survei kepuasan pelanggan di 9 (sembilan) wilayah Indonesia. PkM ini merupakan bentuk pelaksanaan pembelajaran antara tim pengabdi dan pelaku usaha untuk belajar bersama mengenai metode penelitian yang tepat dalam memecahkan masalah mengenai hasil riset kepuasan pelanggan. PkM ini menggunakan webinar online sebagai salah satu metode pengumpulan data di masa pandemi Covid-19. Berdasarkan hal tersebut maka permasalahan yang diangkat adalah apakah media webinar online sebagai metode pengumpulan data untuk para peternak dapat dikatakan optimal? Apa kekuatan dan kelemahan media ini untuk pelaksanaan survei kepuasan?

Berdasarkan latar belakang yang telah dijelaskan ini maka tim pengabdi ingin memberikan pandangan bagaimana kegiatan webinar online ini melatih salah satu nilai kearifan lokal bangsa Indonesia yaitu kreatifitas dosen dan mahasiswa dalam mengumpulkan data survei melalui media online pada para peternak di Indonesia. Dengan demikan, tema tulisan ini adalah "Webinar sebagai Metode Pengumpulan Data di Era Pandemi bagi Para Peternak Indonesia”

\section{METODE PELAKSANAAN}

Kegiatan PkM ini menggunakan metode konsultasi. Metode konsultasi merupakan metode yang memberikan kesempatan kepada peserta untuk berdiskusi mengenai permasalahan yang terjadi [8].

Pelaksanaan program kolaborasi ini berbentuk kerjasama di bidang Pengabdian kepada Masyarakat dosen dan mahasiswa Program Sarjana dan Program Magister Manajemen dengan perusahaan farmasi perternakan.

Tahapan kegiatan PkM ini meliputi:

1. Penyusunan konsep dan instrumen penelitian oleh perusahaan farmasi perternakan dan tim pengembang instrumen dosen Program Studi Sarjana Manajemen dan Program Studi Magister Manajemen Fakultas Bisnis Universitas Kristen Maranatha KBK Pemasaran.

2. Persiapan surveyor (knowledge sharing) dari perusahaan farmasi perternakan dalam bentuk kegiatan guest lecture atau kuliah umum yang diberikan untuk mahasiswa kelas riset pasar Genap 2020/2021. Kegiatan ini merupakan kegiatan yang mendukung program Merdeka Belajar Kampus Merdeka.

3. Pelaksanaan kegiatan webinar online.

4. Pengumpulan data melalui online tools oleh mahasiswa dan tim dosen dalam bentuk kegiatan webinar yang diselenggarakan sebanyak 3 (tiga) kali sesuai dengan kategori konsumen perusahaan farmasi perternakan.

5. Peng-input-an dan pengolahan data oleh tim dosen pengembang instrumen.

6. Penyusunan laporan survei oleh tim dosen pengembang instrumen.

7. FGD hasil survei antara tim dosen pengembang intsrumen dan perusahaan farmasi perternakan sebagai bentuk kegiatan PkM yang berbentuk konsultasi.

\section{TEKNIK PENGUMPULAN DATA}

Kegiatan PkM ini menggunakan metode survei dengan teknik observasi, kuesioner, dan wawancara singkat. Metode survei merupakan metode yang digunakan untuk mengumpulkan infomasi secara deskriptif dan juga dapat digunakan untuk menguji lebih dari satu hipotesis dalam 1 (satu) kali survei [9]. 
Metode observasi digunakan untuk mengamati optimalisasi media webinar online sebagai media survei di era pandemi bagi responden peternak. Sedangkan metode kuesioner dan wawancara singkat digunakan untuk memberikan rekomendasi kepada perusahaan farmasi perternakan mengenai survei kepuasan pelanggan secara kuantitatif dan kualitatif. Kuesioner menggunakan pertanyaan tertutup yang bertujuan untuk mendapatkan analisis data secara kuantitatif mengenai kepuasan. Wawancara singkat bertujuan untuk mendapatkan analisis secara kualitatif sebagai rekomendasi mengenai kepuasan.

Proses pengumpulan data dilakukan langsung bertemu responden melalui kegiatan webinar online yang diadakan oleh Program Studi Sarjana Manajemen Universitas Kristen Maranatha. Media yang digunakan yaitu Google Form yang diisi oleh peserta webinar dan setiap item pertanyaan dibacakan dan dijelaskan oleh surveyor mahasiswa. Pencarian responden dibantu oleh perusahaan farmasi perternakan dengan menyebarkan link pendaftaran webinar.

Lokasi kegiatan PkM ini menggunakan media zoom. Pengumpulan data melalui online tools oleh mahasiswa dan tim dosen dalam bentuk kegiatan webinar online yang diselenggarakan sebanyak 3 (tiga) kali sesuai dengan kategori konsumen perusahaan farmasi perternakan. Periode waktu dan durasi kegiatan pengumpulan data dapat dilihat pada Tabel 1 .

TABEL I

WAKTU DAN DURASI KEGIATAN PKM

\begin{tabular}{|c|l|c|}
\hline No. & \multicolumn{1}{|c|}{ Waktu Kegiatan } & Durasi Kegiatan \\
\hline 1 & Jumat, 28 Mei 2021 & $13.30-16.30$ \\
\hline 2 & Jumat, 04 Juni 2021 & $13.30-16.30$ \\
\hline 3 & Jumat, 11 Juni 2021 & $13.30-16.30$ \\
\hline
\end{tabular}

Tulisan ini lebih membahas mengenai hasil observasi tim pengabdi mengenai optimalisasi media webinar online serta kekuatan dan kelemahan yang perlu dikaji kembali sebagai masukan untuk penerapan teori dan praktik pembelajaran mata kuliah Metode Penelitian dan Riset Pasar.

\section{TEKNIK ANALISIS DATA}

Metode analisis data menggunakan statistika deskripsi dengan metode rata-rata untuk menghasilkan Indeks Kepuasan 2021 serta metode analisis kualitatif untuk menghasilkan rekomendasi bagi perusahaan farmasi perternakan. Metode analisis kualitatif yang digunakan adalah metode ilustratif dengan pendekatan analisis SWOT terutama strength (kekuatan) dan weakness (kelemahan) untuk kepuasan pelanggan serta media survei yang digunakan.

Metode statistika deskripsi adalah analisis yang digunakan untuk menggambarkan data dengan pendekatan salah satunya rata-rata atau mean [10].
Metode ilustratif adalah metode analisis data untuk data kualitatif dengan membandingkan data dengan teori yang digunakan [9].

\section{HASIL DAN PEMBAHASAN}

Kegiatan $\mathrm{PkM}$ ini menggunakan webinar online sebagai media survei kepuasan pelanggan. Pemahaman mengenai webinar online adalah gabungan 2 (dua) kegiatan yaitu survei dan pemberian edukasi dalam 1 (satu) kegiatan webinar. Kegiatan edukasi bertujuan untuk memberikan pembelajaran kepada peserta mengenai topik yang berhubungan dengan "How to survive in Crisis" dari sudut pandang entreprenership, strategic management, dan financial management di industri peternakan. Sedangkan kegiatan survei adalah pengumpulan data mengenai kepuasan peserta sebagai konsumen perusahaan farmasi perternakan.

Tim pengabdi membentuk kepanitian untuk mengadakan webinar online. Persiapan yang dilakukan oleh tim panitia webinar online ini terdiri dari:

1. Pemilihan tim

Kegiatan PkM ini melibatkan tim dosen, mahasiswa, dan perusahaan. Dosen sebagai observer internal dan panitia acara webinar. Mahasiswa terbagi menjadi 2 (dua) bagian yaitu panitia acara webinar dan surveyor kegiatan survei. Panitia surveyor dipilih dari mahasiswa kelas Riset Pasar Genap 2020/2021. Perusahaan sebagai observer eksternal.

2. Pembuatan deskripsi pekerjaan

Deskripsi pekerjaan secara ringkas:

a. Pekerjaan dosen panitia adalah memastikan kegiatan webinar berjalan dengan lancar dari pembukaan sampai dengan evaluasi kegiatan.

b. Pekerjaan dosen observer internal memastikan kegiatan survei kepuasan di setiap room Zoom berjalan dengan lancar dan kondusif.

c. Pekerjaan mahasiswa sebagai panitia adalah tim pelaksana kegiatan webinar.

d. Pekerjaan mahasiswa sebagai surveyor adalah membacakan setiap indikator pernyataan untuk survei kepuasan serta menjawab pertanyaan dari responden mengenai indikator tersebut.

e. Perusahaan sebagai observer adalah berhubungan dengan pencarian calon responden, panitia IT, memantau secara random kondisi pelaksanaan survei kepuasan di room.

3. Pembuatan susunan acara webinar

Panitia dosen membuat susunan acara untuk pelaksanaan kegiatan webinar. Susunan acara webinar online terbagi menjadi 2 (dua) bagian yaitu pelaksanaan survei kepuasan dan pemberian edukasi yang dipresentasikan oleh para pakar dari dosen Prodi 
Sarjana Manajemen dan Prodi Magister Manajemen Fakultas Bisnis Universitas Kristen Maranatha.

4. Pelatihan surveyor

Pelatihan ini bertujuan untuk memberikan pengetahuan kepada surveyor mengenai setiap indikator yang digunakan untuk survei kepuasan. Pengetahuan surveyor digunakan untuk membantu responden memahami indikator survei.

Hasil dan pembahasan observasi tim pengabdi mengenai kegiatan webinar online sebagai berikut:

1. Peserta

Peserta webinar online ini adalah para peternak yang merupakan para pelanggan perusahaan farmasi perternakan. Data peserta dan responden yang mengisi kuesioner dapat dilihat pada Tabel 2.

TABEL 2

DATA PESERTA WEBINAR ONLINE

\begin{tabular}{|c|l|c|c|c|}
\hline No. & \multicolumn{1}{|c|}{ Peserta } & $\begin{array}{c}\text { Webinar } \\
\mathbf{1}\end{array}$ & $\begin{array}{c}\text { Webinar } \\
\mathbf{2}\end{array}$ & $\begin{array}{c}\text { Webinar } \\
\mathbf{3}\end{array}$ \\
\hline 1 & Pendaftaran & 161 & 144 & 174 \\
\hline 2 & Hadir & 65 & 118 & 122 \\
\hline 3 & $\begin{array}{l}\text { Mengisi } \\
\text { Kuesioner }\end{array}$ & 31 & 61 & 42 \\
\hline 4 & $\begin{array}{l}\text { Pengolahan } \\
\text { data }\end{array}$ & 31 & 56 & 41 \\
\hline
\end{tabular}

Tabel 2 menjelaskan bahwa jumlah pendaftar webinar 1, webinar 2, dan webinar 3 sebanyak 479 orang. Pendaftar ini merupakan konsumen perusahaan farmasi perternakan dan calon responden survei kepuasan pelanggan serta sudah memenuhi target responden minimal 284 orang. Data kehadiran sampai dengan pengisian kuesioner mengalami penurunan yang sangat tajam, sehingga target sampel untuk survei kepuasan secara kuantitatif belum terpenuhi.

Adapun beberapa kendala yang dihadapi mengenai data responden sebagai berikut:

a. Data kehadiran webinar 1 terjadi penuruan yang sangat tajam. Hal ini disebabkan karena terjadi kesalahan (error) yang mengakibatkan peserta menunggu terlalu lama di breakout room. Kesalahan tersebut terjadi karena pertama, terjadi kesalahan komunikasi antara panitia internal dan panitia perusahaan. Kedua, gangguan sistem teknologi yang dikendalikan oleh pihak panitia perusahaan. Namun, hambatan di webinar 1 ini menjadi pembelajaran bagi tim pengabdi untuk mengambil keputusan perbaikan dalam pelaksanaan webinar 2 dan webinar 3 .

b. Data kehadiran webinar 2 dan 3 masih mengalami penurunan. Hal ini disebabkan karena pengetahuan peserta mengenai tujuan kegiatan ini. Pengetahuan peserta mengenai acara ini adalah pemberian edukasi mengenai topik yang sudah dipublikasi dalam poster yang dibagikan melalui online kepada peserta. Pada saat peserta hadir dalam acara webinar ini, sesi pertama adalah survei kepuasan sehingga peserta ada yang keluar dari room untuk tidak melanjutkan acara webinar. Selain itu, kehadiran peserta yang tidak sesuai dengan pendaftaran karena kesibukan peserta sebagai peternak yang tidak dapat diprediksi.

c. Data peserta yang mengisi kuesioner mengalami penurunan yang sangat tajam sehingga mengakibatkan kecukupan sampel untuk analisis kuantitatif belum tercukupi. Hal ini disebabkan karena peserta enggan untuk menjadi responden dalam survei kepuasan pelanggan sehingga peserta meninggalkan breakout room dan kembali ke main room atau keluar dari acara ini. Selain itu, penurunan data ini diakibatkan literasi teknologi dari peserta yang terlalu heterogen

2. Panita

Webinar ini terdiri dari 2 (dua) kelompok panitia yaitu panitia internal dan panitia perusahaan. Kedua panitia ini memegang kendali pada saat pelaksanaan webinar. Komunikasi antara kedua panitia ini belum terjalin optimal sehingga mengakibatkan responden menunggu terlalu lama di ruang breakout room dan pelaksanaan survei terlambat.

3. Acara

Acara webinar online terbagi menjadi 2 (dua) bagian yaitu pelaksanaan survei kepuasan dan pemberian edukasi. Dalam 1 (satu) kegiatan dengan pembagian acara yang memiliki tujuan berbeda mengakibatkan kerancuan bagi peserta. Tujuan acara yang tidak jelas mengakibatkan peserta mengalami kebingungan.

4. Peralatan

Di satu sisi, teknologi membantu mempercepat dan membuat sederhana pekerjaan manusia. Di sisi lain, teknologi dapat mengakibatkan pekerjaan manusia menjadi terhambat. Gangguan sistem IT yang tidak bisa diramalkan akan mengakibatkan acara menjadi terhenti. Selain itu, kesiapan user sebagai pengguna teknologi juga akan menjadi penghambat pekerjaan manusia.

Hasil kegiatan PkM ini menjadi pembelajaran bagi tim pengabdi dan pelaku usaha untuk menerapkan teori riset pasar dan metode penelitian. PkM ini mengandung unsur Tri Dharma Perguruan Tinggi dan MBKM. Tim pengabdi dapat melakukan kolaborasi antara pendidikan, penelitian, dan pengabdian. Luaran PkM ini berbentuk modul pembelajaran dengan topik riset pasar dan metode penelitian yang menjadi sarana diskusi pembelajaran mata kuliah Riset Pasar dan Metode Penelitian selanjutnya 
Berdasarkan analisis hasil $\mathrm{PkM}$ ini, salah satu hambatan menurunnya jumlah sampel adalah karakteristik responden dari sisi kesiapan teknologi. Dengan demikian, keberlanjutan PkM ini adalah bekerjasama dengan para perusahaan peternakan di Indonesia untuk mengembangkan komunitas peternak dari sisi pengembangan manajemen usaha peternakan yang diawali dengan memberikan pembekalan mengenai peranan teknologi sebagai pendukung dalam mengelola usaha peternakan. Selanjutnya, Tim Pengabdi akan melakukan penelitian kualitatif untuk mengetahui kebutuhan yang perlu dikembangkan oleh para peternak dalam mengembangkan manajemen perusahaan.

Refleksi yang dapat diperoleh dari serangkaian kegiatan PkM ini adalah tim pengabdi dapat mengamati proses pengumpulan data melalui webinar. Melalui kegiatan PkM ini, tim pengabdi dapat merenungkan bahwa teknologi akan membantu pekerjaan manusia menjadi lebih sederhana, mudah, dan cepat. Namun disisi lain, teknologi dapat menjadi penghambat kelancaran pekerjaan. Dengan demikian, tim pengabdi dapat belajar melalui kendala yang dihadapi dalam pelaksanaan webinar ini khususnya kendala kesiapan penggunaan teknologi. Tim pengabdi perlu mempersiapkan strategi antisipasi atau rencana lain jika terjadi kendala dalam penggunaan teknologi. Selain itu, tim pengabdi perlu lebih cermat mempersiapkan peserta khususnya peserta dengan karakteristik yang heterogen dari sisi demografi dan psikografi (tingkat usia, tingkat pendidikan, tingkat pengetahuan penggunaan teknologi, dan lainnya).

\section{KESIMPULAN DAN SARAN}

Penggunaan media webinar online yang dilakukan dalam PkM ini merupakan hasil internalisasi nilai kearifan lokal dalam dunia pendidikan yang berupa nilai kreatifitas dan kemampuan adaptasi dosen dan mahasiswa Prodi Sarjana Manajemen dan Magister Manajemen Fakultas Bisnis Universitas Kristen Maranatha. Berdasarkan hasil observasi tim pengabdi mengenai penggabungan kegiatan survei dan pemberian edukasi dalam 1 (satu) kegiatan webinar online masih belum optimal sehingga mengakibatkan tujuan awal mengenai survei kepuasan pelanggan secara kuantitatif masih belum memenuhi target sampel. Perusahaan dan tim pengabdi perlu memikirkan berbagai pertimbangan dan memiliki alternatif lain ketika menggabungkan acara dengan tujuan yang berbeda.

Dengan demikian saran tim pengabdi adalah penggunaan media menjadi sangat penting dalam pengumpulan data untuk survei kepuasan. Untuk itu, perusahaan perlu mempertimbangkan beberapa hal antara lain:

\section{Pengetahuan responden}

Keberhasilan suatu kegiatan diperlukan pengetahuan dari peserta mengenai tujuan kegiatan tersebut. Peserta yang hadir memiliki motivasi kehadiran yang tinggi jika mengetahui tujuan kegiatan. Kerancuan tujuan kegiatan akan berdampak pada demotivasi peserta untuk mengikuti kegiatan. Dengan demikian, peserta perlu mengetahui tujuan kegiatan dengan jelas agar termotivasi untuk mengikuti kegiatan tersebut.

2. Keinginan responden

Peserta perlu memberikan persetujuan bahwa akan dijadikan responden untuk penelitian tertentu. Keinginan peserta untuk menjadi subjek penelitian menjadi kode etik yang sebaiknya tidak dilanggar oleh tim peneliti.

3. Karakteristik konsumen sebagai calon responden Jika perusahaan memiliki calon responden dari konsumen yang heterogen antara lain: dari sisi demografi dan psikografi (tingkat usia, tingkat pendidikan, tingkat pengetahuan penggunaan teknologi, dan lainnya) disarankan untuk melakukan penyesuaian pemilihan media dan karakteristik konsumen.

\section{Karakteristik Panitia Pelaksana}

Panitia perlu memiliki kemampuan penggunaan teknologi yang mumpuni jika menggunakan media online. Jika terjadi permasalahan dalam gangguan sistem dapat memberikan keputusan yang tepat. Selain itu, panitia perlu memiliki kemapuan komunikasi yang andal sehingga dapat melakukan koordinasi dengan tepat dan cepat.

\section{UCAPAN TERIMA KASIH}

Terima kasih kepada perusahaan farmasi perternakan, Program Sarjana Manajemen, dan Program Magister Manajemen Fakultas Bisnis Universitas Kristen Maranatha yang telah bersedia memberi kesempatan kepada dosen dan mahasiswa untuk melaksanakan kegiatan ini. Berkat dukungan dana dan izin kegiatan maka kegiatan PkM ini dapat terselenggara dengan lancar.

\section{DAFTAR PUSTAKA}

[1] R. B. Putra and H. Putri, "Literature Review: Model Pengukuran Kinerja Dosen dan Organizational Citizenship Behavior Berdasarkan Karakteristik Individu, Budaya Kerja dan Perilaku Individu," Jurnal Ilmu Manajemen Terapan (JIMT), vol. 2, no. 4, pp. 485-512, 2021.

[2] M. Asbari and D. Novitasari, "Pengaruh Aktivitas Berbagai Pengetahuan dan Mediasi Budaya 
terhadap Kemampuan Inovasi Guru," Jurnal Manajemen dan Supervisi Pendidikan (JMSP), vol. 5, no. 1, pp. 50-50, 2020.

[3] E. L. F. Ahsani and N. R. Azizah, "Implementasi Literasi Budaya dan Kewargaan untuk Mengembangkan Keterampilan Sosial Siswa Madrasah Ibtidaiyah di Tengah Pandemi," Jurnal Pendidikan Kewarganegaraan, vol. 11, no. 1, pp. 7-16, 2021.

[4] Y. Hendayana. [Online]. Available: https://dikti.kemdikbud.go.id/kabardikti/kabar/fokus-tri-dharma-perguruan-tinggimenuju-center-of-excellence/.. [Accessed 8 September 2021].

[5] CC. [Online]. Available: https://www.ibik.ac.id/program-merdeka-belajarkampus-merdeka/.. [Accessed 8 September 2021].

[6] S. Fajri and T. Trisuryanti, "Gagasan Sistem Among Ki Hajar Dewantara Dalam Membangun Pendidikan di Indonesia Sejak 1922 Sampai Dengan 2021," Tarikhuna: Journal of History and History Education, vol. 3, no. 1, pp. 18-27, 2021.

[7] A. Cahyani and A. S. Putri, "Meninjau Respon Masyarakat Terkait Pemenuhan Hak Ekosob Melalui Kebijakan Protokol Kesehatan di Masa Pandemi," in Seminar Nasional Hukum Universitas Negeri Semarang, Semarang, 2021.

[8] F. Fitriyana, A. Nuryani, T. Rosyati and Y. Gusvia, "Pelatihan Pemanfaatan Marketplace pada UMKM Dalam Masa Covid 19," Dedikasi PKM UNPAM, vol. 2, no. 2, pp. 206-211, 2021.

[9] W. L. Neuman, Social Research Methods: Qualitative and Quantitative Approaches, United State of America: Pearson Education, 2014.

[10] R. R. Anderha and S. Maskar, "Pengaruh Kemampuan Numerasi Dalam Menyelesaikan Masalah Matematika Terhadap Prestasi Belajar Mahasiswa Pendidikan Matematika," Jurnal Ilmiah Matematika Realistik (JI-MR), vol. 2, no. 1, pp. 1-10, 2021. 